\title{
Coping strategies and characteristics of the nursing staff of a private hospital
}

\author{
Estratégias de Coping e características de trabalhadores de enfermagem de hospital privado \\ Estrategias de enfrentamiento y características de trabajadores de enfermería de hospital \\ privado
}

Eliane Raquel Rieth Benetti ${ }^{1}$, Eniva Miladi Fernandes Stumm² ${ }^{2}$ Teresinha Heck Weiller ${ }^{3}$, Karla de Melo Batista ${ }^{4}$, Luis Felipe Dias Lopes ${ }^{3}$, Laura de Azevedo Guido ${ }^{3}$

Objective: to analyze the relationships between sociodemographic/functional characteristics and the coping strategies used by the nursing staff of a private hospital. Methods: it is a quantitative, analytical and cross-sectional study developed with 209 nursing workers. Data were collected sociodemographic/functional characterization and form inventory of the coping strategies. Results: positive reassessment, social support and problem solving were the most used coping factors. There was statistically significant difference between self-control and sex; social support and salary range; acceptance of responsibility and the variables age, number of children, training and salary. The staff use strategies focused on emotions and problems to cope with or to minimize stressors at work. Conclusion: educational activities need to be encouraged aiming to instrumentalize them to do the evaluation of stressors and to use resolutive coping strategies.

Descriptors: Nursing; Psychological Stress; Adaptation, Psychological; Occupational Health.

Objetivo: analisar as relações entre características sociodemográficas/funcionais e as estratégias de Coping utilizadas pelos trabalhadores de enfermagem de um hospital privado. Método: estudo quantitativo, analítico e transversal desenvolvido com 209 trabalhadores de enfermagem. Os dados foram coletados por meio de formulário para caracterização sociodemográfica/ funcional e Inventário de Estratégias de Coping. Resultados: reavaliação Positiva, Suporte Social e Resolução de Problemas foram os Fatores de Coping mais utilizados. Houve diferença estatística significativa entre Autocontrole e sexo; Suporte Social e Faixa salarial; Aceitação de Responsabilidade e as variáveis idade, número de filhos, treinamento e faixa salarial. Os trabalhadores utilizam estratégias centradas na emoção e no problema para enfrentar ou minimizar estressores no trabalho. Conclusão: ações educativas devem ser incentivadas visando instrumentalizá-los para avaliação dos estressores e uso de estratégias de Coping resolutivas.

Descritores: Enfermagem; Estresse Psicológico; Adaptação Psicológica; Saúde do Trabalhador.

Objetivo: analizar las relaciones entre características sociodemográficas/funcionales y las estrategias de enfrentamiento utilizadas por trabajadores de enfermería de un hospital privado. Método: estudio cuantitativo, analítico y transversal, desarrollado con 209 trabajadores de enfermería. Datos fueron recogidos, mediante Formulario sociodemográfico/funcional e Inventario de Estrategias de Enfrentamiento. Resultados: reevaluación Positiva, Apoyo Social y Resolución de Problemas fueron los factores de enfrentamiento más utilizados. Hubo diferencia estadísticamente significativa entre Autocontrol y sexo; Apoyo Social y salario; Aceptación de Responsabilidad y las variables edad, número de hijos, entrenamiento y salario. Los trabajadores utilizan estrategias centradas en la emoción y en el problema para enfrentarse o minimizar los estresores en el trabajo. Conclusión: acciones educativas deben ser alentadas para instrumentalizarlos a evaluar los estresores y utilizar estrategias de enfrentamiento efectivas.

Descriptores: Enfermería; Estrés Psicológico; Adaptación Psicológica; Salud Laboral.

\footnotetext{
${ }^{1}$ Hospital Universitário de Santa Maria. Ijuí, RS, Brazil.

${ }^{2}$ Universidade Regional do Noroeste do Estado do Rio Grande do Sul. Ijuí, RS, Brazil.

${ }^{3}$ Universidade Federal de Santa Maria. Santa Maria, RS, Brazil.

${ }^{4}$ Universidade Federal do Espírito Santo. Vila Velha, ES, Brazil.

Corresponding author: Laura de Azevedo Guido

Rua Fioravante Antonio Spiazzi, 78. Cerrito, Km 03, CEP: 97095-180. Santa Maria, RS. Brazil. E-mail: lguido344@gmail.com
} 


\section{Introduction}

The world of work has undergone changes due to globalization and technological innovations. These changes can be evaluated by individuals as stressful and they demand skills to deal with them ${ }^{(1)}$. In this context, one highlights the hospital, an environment where some situations and working conditions can be evaluated as stressful by health professionals as they exceed the capacity of adaptation, influencing the behavior and health of these individuals, in particular the nursing staff.

In this sense, in the nursing practice, some situations can be evaluated as stressful, among them: the small number of professionals, the excess of activities, responsibility for people's care, ambiguity and conflict of roles, decision making, the complexity of interpersonal relationships, work shifts, the interface home/work and the fulfillment of long and stressful working hours ${ }^{(2-3)}$. Due to a situation considered as stressful, workers use strategies to face them, called coping.

Coping strategies represent a set of efforts, both cognitive and behavioral, employed to deal with internal and/or external demands that are assessed as surplus to the adaptive resources of an individual ${ }^{(4)}$. They are elaborated from the assessment of the situation and of the environment, according to past experiences, to try to solve or minimize the effects of a stressor ${ }^{(4)}$. In the 80s, these strategies were classified into two types namely: coping focused on the problem and coping focused on the emotion ${ }^{(4)}$.

Coping focused on the problem includes efforts to identify the problem, define alternative solutions, evaluate the costs and benefits of actions, adopt postures to change what is possible and, if necessary, learn new skills in relation to the desired or expected result ${ }^{(4)}$. Individuals seek to control the stressor and actions are directed to decrease it or eliminate it, and they are considered more resolving strategies ${ }^{(4-5)}$.

Coping focused on the emotion corresponds to strategies that derived from defensive processes in which individuals avoid to confront the threat ${ }^{(4-5)}$. In this strategy, the individual's emotion is modulated before the stressful situation and thus it reduces the unpleasant sensation caused by the stress ${ }^{(4)}$.

Although different, the strategies focused on the problem and on the emotion complement each other and they can be used simultaneously by an individual. Thus, characterized as a process, coping is dynamic and allows people to exchange thoughts and actions in dealing with stressful situations, besides the evaluation and definition of the strategy to be used based on the assessments and ongoing reassessments of the relationship person-environment ${ }^{(6)}$.

It is noteworthy that the experience of stressors in the workplace and the failure to adapt to them may lead an individual to get sick. Thus, one points out the importance of the way in which a worker faces such situations day-to-day in his work environment ${ }^{(5)}$. Therefore, interactions between workers and their work environment, organizational conditions, as well as their personal characteristics, needs, experiences and perceptions of the world are factors that affect the relationship between stressors and coping ${ }^{(7)}$.

Thus, it is understood that identifying the coping strategies used by the nursing staff in hospitals is important because the use of these strategies can minimize the effects of stressors, prevent further stress and interfere with the well-being and the health of these workers. In addition, this study contributes to the construction of knowledge about the subject considering that it covers nursing workers from different categories of a private hospital.

Given the above, this study aims to analyze the relationships between sociodemographic/functional characteristics and coping strategies used by the nursing staff of a private hospital.

\section{Method}

This is a cross-sectional, analytical study with quantitative approach, developed in a private hospital in the northwest of Rio Grande do Sul, Brazil. It included 
nursing workers who worked in the institution for a period longer than three months. Those on vacation or away for licenses of any kind were excluded. Thus, 28 nurses, 174 nursing technicians and seven nursing auxiliaries participated, totaling 209 workers.

Data collection was carried out between September and October 2012 through a sociodemographic and functional characterization form and through the inventory of coping strategies. This questionnaire was adapted and validated for the Brazilian reality ${ }^{8}$, composed of 66 items covering thoughts and actions that people use to deal with internal or external demands of a stressor. The instrument items are presented in Likert scale of four points, where: zero corresponds to "no use of the strategy"; one to "used it a little"; two to "used it a lot" and three to "used it in large quantities"(8). Thus, this inventory allows one to check the frequency that the thoughts and actions are used to manage stressors in the work environment ${ }^{(8)}$.

The items are divided into eight factors, namely: Confrontation (items 6, 7, 17, 28, 34, 46), Withdrawal (items 12, 13, 15, 21, 41, 44), Self-control (items 10.14, $35,43,54,62,63$ ), Social support (items 8, 18, 22, 31, 42, 45), Acceptance of responsibility (items 9, 25, 29, 51), Escape and avoidance (items 11, $16,33,40,47$, 50, 58, 59) Problem solving (items 1, 26, 39, 48, 49, 52) and Positive Reassessment (items 20, 23, 30, 36, $38,56,60$ ) . Items $2,3,4,5,19,24,27,32,37,53,55$, $57,61,64,65$ and 66 do not form any factors and do not represent any value in the coping assessment ${ }^{(8)}$.

After collection, one built up a database in the software Excel for Windows, with independent doubled typing, and the analysis was given by the program Statistical Package for Social Sciences Version 17.0.

For the inventory analysis of coping strategies one summed up the scores assigned to a particular item of the instrument and divided that by the number of research subjects, resulting in the average item for the population. This process was repeated for each inventory item. Thus, the highest average items accounted for the actions mostly used by the nursing staff to cope with stressors. Furthermore, to identify the average by factor, one carried out the sum of the scores assigned to the items of the inventory of the same factor, divided by the number of items composing that factor, obtaining the average of the subject in each factor of the instrument. With the sum of these averages divided by the number of subjects, one obtained the population average by factor of the inventory of coping strategies. Thus, the highest average factors were considered the most widely used to deal with stress in the workplace.

The assessment of the reliability was performed by analyzing the internal consistency of the items that make up the instrument through Cronbach's alpha coefficient. The alpha ranges from zero to one, and the higher the value, the greater the internal consistency of the instrument ${ }^{(9)}$. The qualitative variables were expressed as absolute (n) and relative frequency (\%) and the quantitative variables in descriptive measures (minimum, maximum, average and standard deviation).

Mann-Whitney test was used to compare the scores of two independent groups. With this test, the coping factors were compared with the variables: gender, training, practice of physical activities and leisure activities. Kruskal-Wallis test was used to verify if more than two independent groups differ among themselves. This test was used to compare the coping factors with the variables marital status, number of children, age and salary range. $P$ values $<0.05$ were considered statistically significant, with a confidence interval of $95 \%$.

This study was developed together with the research group: Work, Health, Education and Nursing in the theme "Stress, Coping and Burnout", from the Federal University of Santa Maria/RS, it contemplates the determinations of the Resolution 196/96 from the National Health Council and integrates the research project "Stress and Coping among nursing staff in 
hospitals" approved by the Research Ethics Committee of the university under Opinion No. 74051/2012.

\section{Results}

At the time of data collection, there were 255 nursing workers at the hospital. Out of these, 211 met the eligibility criteria. However, 209 gave back the research protocol answered, which is a population of access composed of $99.05 \%$ of the workers.

During the analysis of the reliability of the 66 items of the inventory of coping strategies, Cronbach's alpha was 0.897 , which proves satisfactory internal consistency to the instrument for this population ${ }^{(9)}$.

It was found that $91.49 \%$ of the employees are female, $61.24 \%$ were married, $57.42 \%$ had children and with an average age of 33.8 years old (SD=8.31). As for the professional category, $83.25 \%$ are nursing technicians, $13.40 \%$ nurses and $3.35 \%$ nursing assistants. Still, one verifies that $77.99 \%$ completed their training (college degree or professional course) less than ten years ago, $69.86 \%$ have worked in the institution for more than two years and $54.54 \%$ work on the unit where they are allocated for a period greater than two years.

It is observed that $38.76 \%$ of the employees are chosen to work at night, $55.02 \%$ chose the unit where they would like to work and $51.20 \%$ received training before starting their work activities. It is noteworthy that $53.11 \%$ have another job or academic activity, among which $63.96 \%$ work in another hospital, $18.02 \%$ have paid work outside the hospital area, 9.01\% are undergraduate students and 9.01\% graduate students. It is observed that $52.15 \%$ of the workers practice some physical activity and $67.94 \%$ enjoy leisure moments.

In Table 1, coping factors are presented and their descriptive measures.
Table 1 - Descriptive measures of the factors of the Inventory of Coping Strategies used by nursing workers

\begin{tabular}{lcccc}
\hline Factors & Average & $\begin{array}{c}\text { Standard } \\
\text { Deviation }\end{array}$ & $\begin{array}{c}\text { Mini- } \\
\text { mum }\end{array}$ & $\begin{array}{c}\text { Maxi- } \\
\text { mum }\end{array}$ \\
\hline Positive reassessment & 1.88 & 0.44 & 0 & 3 \\
Social support & 1.87 & 0.51 & 0 & 3 \\
Problem solving & 1.83 & 0.44 & 0 & 3 \\
Self-control & 1.81 & 0.45 & 0 & 3 \\
Acceptance of responsibility & 1.79 & 0.44 & 0 & 3 \\
Withdrawal & 1.68 & 0.45 & 0 & 3 \\
Confrontation & 1.63 & 0.48 & 0 & 3 \\
Escape and avoidance & 1.58 & 0.50 & 0 & 3 \\
\hline
\end{tabular}

Next, on Table 2, coping factors are presented and their descriptive measures according to the nursing workers' functional category.

Table 2 - Descriptive measures of the inventory factors of coping strategies by functional category

Functional Category

\begin{tabular}{|c|c|c|c|}
\hline \multirow{2}{*}{$\begin{array}{l}\text { Factors of the inventory of } \\
\text { coping strategies }\end{array}$} & \multicolumn{3}{|c|}{ 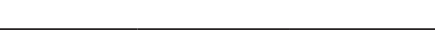 } \\
\hline & $\begin{array}{l}\text { Nurse } \\
\left(\bar{x}_{ \pm d p}\right)\end{array}$ & $\begin{array}{c}\text { Technician } \\
\left(\bar{x}_{ \pm} \mathrm{dp}\right)\end{array}$ & $\begin{array}{l}\text { Assistant } \\
(\bar{X} \pm d p)\end{array}$ \\
\hline Confrontation & $1.64 \pm 0.47$ & $1.63 \pm 0.49$ & $1.47 \pm 0.39$ \\
\hline Withdrawal & $1.58 \pm 0.47$ & $1.69 \pm 0.44$ & $1.80 \pm 0.71$ \\
\hline Self-control & $1.90 \pm 0.45$ & $1.79 \pm 0.45$ & $1.74 \pm 0.33$ \\
\hline Social support & $1.99 \pm 0.45^{*}$ & $1.85 \pm 0.52$ & $1.92 \pm 0.46$ \\
\hline Acceptance of responsibility & $1.92 \pm 0.40$ & $1.77 \pm 0.44$ & $1.64 \pm 0.47$ \\
\hline Escape-avoidance & $1.71 \pm 0.51$ & $1.57 \pm 0.50$ & $1.35 \pm 0.39$ \\
\hline Problem solving & $1.85 \pm 0.41$ & $1.83 \pm 0.45$ & $1.7 \pm 10.41$ \\
\hline Positive reassessment & $1.91 \pm 0.32$ & $1.88 \pm 0.45^{*}$ & $1.96 \pm 0.60 *$ \\
\hline
\end{tabular}

Figure 1 presents the items with bigger and lower averages by factor of the inventory, considered the actions, respectively, most and least used by the nursing staff to deal with stressors. 


\begin{tabular}{|c|c|c|}
\hline Factors & Most used strategies & Least used strategies \\
\hline Confrontation & $\begin{array}{l}\text { I refused to go back and battled for what I wanted } \\
(1.93 \pm 0.75)\end{array}$ & $\begin{array}{l}\text { I faced it as a big challenge, I did something very } \\
\text { risky }(1.43 \pm 0.66)\end{array}$ \\
\hline Withdrawal & I tried to forget the unpleasant situation $(2.04 \pm 0.73)$ & I agreed with the fact, I accepted my fate $(1.38 \pm 0.66)$ \\
\hline Self-control & $\begin{array}{l}\text { I mentally analyzed what to do and what to say } \\
(1.97 \pm 0.73)\end{array}$ & $\begin{array}{l}\text { I did not let other people know about the real } \\
\text { situation }(1.27 \pm 0.54)\end{array}$ \\
\hline Social support & $\begin{array}{l}\text { I talked with (an)other person(s) about the problem, } \\
\text { looking for more data about the situation }(1.94 \pm 0.77)\end{array}$ & $\begin{array}{l}\text { I looked for a friend or relative to ask for advice } \\
(1.79 \pm 0.77)\end{array}$ \\
\hline Acceptance of responsibility & $\begin{array}{l}\text { I promised to myself that things will be different next } \\
\text { time }(2.01 \pm 0.73)\end{array}$ & $\begin{array}{l}\text { I realized that the problem was caused by myself } \\
(1.38 \pm 0.66)\end{array}$ \\
\hline Escape-avoidance & $\begin{array}{l}\text { I wished the situation ended or that somehow it } \\
\text { disappeared }(1.90 \pm 0.79)\end{array}$ & $\begin{array}{l}\text { I tried to run away from people in general } \\
(1.26 \pm 0.61)^{* *}\end{array}$ \\
\hline Resolution of problems & $\begin{array}{l}\text { I knew what should be done, so I doubled my efforts } \\
\text { to do whatever was necessary }(2.02 \pm 0.72)\end{array}$ & $\begin{array}{l}\text { I searched on past experiences a similar situation } \\
(1.61 \pm 0.63)\end{array}$ \\
\hline Positive re-assessement & I prayed $(2.31 \pm 0.80)^{*}$ & I found new beliefs $(1.54 \pm 0.71)$ \\
\hline
\end{tabular}

Figure 1 - Most and least used coping strategies by nursing staff

Concerning the relationship between sociodemographic variables and the coping factors, there is a significant negative correlation of low intensity between liability acceptance and age ( $\mathrm{r}=-$ 0.168, $\mathrm{p}=0.014$ ).

There has been a statistically significant difference between the factor self-control and the gender of the nursing workers $(\mathrm{p}=0.041)$, and the females have a higher average $(1.82 \pm 0.43)$ when compared to males $(1.64 \pm 0.52)$.

It was found a statistically significant difference between the acceptance of responsibility and the number of children ( $\mathrm{p}=0.0438)$, and the workers who have more than three children have a higher average $(\bar{x}=2.28, S D=0)$ on this factor. It is also noticed a statistically significant difference between this factor and the variable training ( $\mathrm{p}=0.046)$, and the workers who did not receive training before starting their activities have a higher average $(1.86 \pm 0.47)$ when compared with those who did $(1.72 \pm 0.40)$. There is still a statistically significant difference between acceptance of responsibility and salary range $(\mathrm{p}=0.017)$, and this factor is less used $(1.70 \pm 0.43)$ by the workers who earn up to $R \$ 1,499.00$ when compared to other groups.
There is a statistically significant difference between Social Support and salary range $(\mathrm{p}=0.0039)$, making this factor the least used $(1.63 \pm 0.52)$ by workers who earn more than $\mathrm{R} \$ 2,999.00$ when compared to the other salary ranges.

No significant differences were identified between the coping factors used and the variables practice of physical activity and conduction of leisure activities.

\section{Discussion}

It was found that the Positive Reassessment $(1.88 \pm 0.44)$, the Social Support $(1.87 \pm 0.51)$ and the Problem Solving $(1.83 \pm 0.44)$ were the factors with highest average, considered as the most used by nursing staff to cope with stressors in the workplace. The positive reassessment was the most frequently used factor by nursing technicians and nursing assistants and the social support the most used by nurses. This result is similar to that observed in a study with oncology nurses in which it was observed that the positive reassessment was the most used factor, followed by problem solving, self-control and social support ${ }^{(10)}$. 
Furthermore, in a randomized clinical trial conducted with nursing professionals from a university hospital in São Paulo, the positive reassessment was the most used coping factor by the study population ${ }^{(11)}$. In research with nurses and nursing technicians from a center of adult intensive care, with application of the Coping Strategies Scale, it was found that Positive Reinterpretation was the strategy most commonly used by the study subjects ${ }^{(12)}$. This strategy is the resizing of the stressor from the modification of the emotional state and, although it is not aimed directly to the resolution of the problem, it precedes the action and facilitates emotional balance ${ }^{(12)}$.

The positive reassessment refers to cognitive strategies for acceptance of the reality in which the individual tries to find some ways to mitigate the situation or focuses on the positive aspects of it in order to reduce the emotional charge of the event and thus, resize the stressor ${ }^{(4)}$. While this strategy is centered on emotion, it precedes the action and can contribute to cope with the stressful situation.

In a study conducted with nurses in the emergency services of three Iranian teaching hospitals, one found that the most commonly used factors by them were the self-control and the positive reassessment and the least used was the acceptance of responsibilities ${ }^{(13)}$. The authors report that selfcontrol is a common cultural trait of Asian nurses and that the positive reassessment is often used because of its religious dimension, mainly because the Iranian nurses use religious coping ${ }^{(13)}$.

It was found that, even in countries with different laws, cultures and habits, spirituality is used to face stressful situations. In the present study, the strategy "I prayed", which integrates the positive reassessment factor, was the most used by the nursing staff. It is considered that, in situations that require decision making and immediate work from professionals, this strategy was used in order to seek, in spirituality, strength to face the stressors.

With regard to social support, it was observed that this factor was used by subjects from different studies, which means that individuals resort to people from their social environment in an attempt to get emotional support ${ }^{(6,10)}$. In a study with nurses from operating rooms and anesthesia recovery rooms, the factor problem solving was the most used and the social support one of the most used ${ }^{(6)}$. This last factor is characterized by the availability of people who show concern, appreciation and affection, like friends, family members and co-workers ${ }^{(11)}$.

The problem solving, considered a strategy focused on the problem, was, in some studies, the most used factor ${ }^{(13-14)}$. By using this factor, the individual defines the problem, numbers and compares the alternatives with the desired results, as well as selects and sets an action plan ${ }^{(4)}$. Thus, it is considered that, as workers identify their environmental demands, they get ready to face the stressful situation in an attempt to change it.

Thus, in a survey conducted with the inventory of coping strategies among nurses from a philanthropic hospital, one noticed the predominance of the factors Problem Solving, Positive Reassessment and Social Support ${ }^{(14)}$. Similar results were also found in a study with nurses from the blood-oncology unit of a university hospital, using the Occupational Coping Scale, where it was observed that the coping strategy most often used by them was Control ${ }^{(15)}$. In studies with nurses from hospitals ${ }^{(1)}$, from surgical clinical units ${ }^{(16)}$ and internal medicine ${ }^{(17)}$, one verified through the inventory of coping strategies that the Problem Solving Factor was the most used by these populations.

Based on this, one highlights the shared use of strategies focused on the problem and on the emotion before stressful situations, considering that the Problem Solving, the Positive reassessment and the Social Support were observed in this study as the most used strategies for coping with stressors. On the other hand, some studies differ in the prevalence of strategies focused on the problem $^{(1,16,17)}$ or on the emotion ${ }^{(11-14)}$. 
This is because the use of coping strategies depends on the assessment of the stressor by individuals, who may act differently across the same situation. In addition, the individual characteristics of each worker can interfere with this assessment and with the option for more or less solving strategies ${ }^{(1,10,18)}$.

In this sense, there was a significant negative low intensity correlation between Acceptance of Responsibility and Age Range ( $\mathrm{r}=-0.168, \mathrm{p}=0.014$ ) which means that the higher the age, the lower the use of this factor by the workers. Although one cannot generalize, empirically, it is considered that the experience at work and maturity may favor the identification and evaluation of stressors, and allow a safer choice between one or the other coping strategy.

Considering the results of this study, it is stated that the nursing staff use coping strategies focused on the problem and on the emotion to face stressors in the hospital environment. In this sense, coping can be seen as a process determined by the cognitive and dependent evaluation of the context where an individual is inserted and their life stories and previous experiences. Still, the sociodemographic and functional characteristics of the workers can interfere in the definition of the strategy to be used.

In this perspective, coping can be learned. It is, therefore, important that nursing workers are trained about coping in order to promote the choice of more effective strategies for coping with stressors in the workplace.

\section{Conclusion}

This study enabled the identification of coping factors mostly used by the nursing staff of a private hospital, as well as the analysis of relations among the inventory factors of coping strategies and the sociodemographic and functional variables.

The statistically significant differences found between the inventory factors and the sociodemographic and functional variables show that they interfere with the assessment of the stressor and with the choice and use of the coping strategies.

Thus, analyzing the coping strategies used by the nursing staff from a private hospital can enable the institution managers to understand how these individuals face stressors at work; and it can also facilitate the planning of educational activities in order to equip workers for the use of coping strategies that minimize stress at work. It is believed that the combination of organizational support and individual effort can be a positive association to deal appropriately with occupational stressors, to a good professional performance and to an adequate productivity to the work demands.

The type of institution where the study was conducted can be considered a limiting factor for the assessment of coping, since the disclosed data are relevant to a particular population group, with its cultural, economic, social and functional conformation, which has the same features and capabilities in all regions of the country. One highlights that in private hospitals there are certain requirements in relation to productivity and attendance, so one must interpret and apply the results of this phenomenon with caution. Also, coping is a dynamic process and how individuals face stressors can change over time; for this reason, the cross-sectional design used represents the perception of nursing workers faced with the context they lived in the period of data collection.

\section{Collaborations}

Benetti ERR and Guido LA contributed to the construction of the project, to the conduction of the study, data analysis and writing. Weiller TH and Batista KM contributed in construction of the project and writing. Stumm EMF contributed in data analysis and writing. Lopes LFD in building the study design and data analysis. 


\section{References}

1. Guido LA, Linch GFC, Pitthan LO, Umann J. Stress, coping and health conditions of hospital nurses. Rev Esc Enferm USP. 2011; 45(6):1434-9.

2. Rodrigues VMCP, Ferreira ASSF. Stressors in nurses working in Intensive Care Units. Rev Latino-Am Enfermagem. 2011; 19(4):1025-32.

3. Teixeira CAB, Reisdorfer E, Gherardi-Donato ECS. Occupational stress and coping: reflection on the concepts and practice of Hospital nursing. Rev Enferm UFPE On line [Internet]. 2014 [cited 2014 Sept 12]; 8(supl 1):2528-32. Available from: http://www.revista.ufpe.br/revistaenfermagem/ index.php/revista/article/view/6279/pdf_5765

4. Lazarus RS, Folkman S. Stress, appraisal and Coping. New York: Springer; 1984.

5. Schreuder JA, Roelen CA, Groothoff JW, Van der Klink JJ, Mageroy N, Pallesen S et al. Coping styles relate to health and work environment of Norwegian and Dutch hospital nurses: a comparative study. Nurs Outlook. 2012; 60(1):3743.

6. Guido LA, Bianchi ERF, Linch GFC. Coping among nurses of the operating room and recovery room. Rev Enferm UFPE On Line [Internet]. 2009 [cited 2013 Jan 10]; 3(4):35-41. Available from: http:// www.revista.ufpe.br/revistaenfermagem/index. php/revista/article/viewFile/90/pdf_945

7. Gomes SFS, Santos MMMCC, Carolino ETMA. Psycho-social risks at work: stress and coping strategies in oncology nurses. Rev Latino-Am Enfermagem. 2013; 21(6):1282-9.

8. Savóia MG, Santana PR, Mejias NP. Adaptação do inventário de estratégias de Coping de Folkman e Lazarus para o português. Psicol USP. 1996; 7(12):183-201.

9. Hora HRM, Monteiro GTR, Arica J. Confiabilidade em Questionários para Qualidade: um estudo com o coeficiente Alfa de Cronbach. Produto Produção. 2010; 11(2):85-103.
10. Rodrigues AB, Chaves EC. Stressing factors and coping strategies used by oncology nurses. Rev Latino-Am Enfermagem. 2008; 16(1):24-8.

11. Kurebayashi LFS, Gnatta JR, Borges TP, Silva MJP. Applicability of auriculotherapy in reducing stress and as a coping strategy in nursing professionals. Rev Latino-Am Enfermagem. 2012; 20(5):980-7.

12. Colossi EG, Calesso-Moreira M, Pizzinato A. Estratégias de enfrentamento utilizadas pela equipe de enfermagem de um CTI adulto perante situações de estresse. Rev Ciênc Saúde. 2011; 4(1):14-21.

13. Gholamzadeh S, Sharif F, Rad FD. Sources of occupational stress and Coping strategies among nurses who work in Admission and Emergency Departments of Hospitals related to Shiraz University of Medical Sciences. Iran J Nurs Midwifery Res. 2011; 16(1):41-6.

14. Lages MGG, Costa MAO, Lopes TR, Amorin FCS, Araujo Neto AP, Nascimento IRD et al. Estratégias de Enfrentamento de Enfermeiros frente ao Paciente Oncológico Pediátrico. Rev Bras Cancerol. 2011; 57(4):503-10.

15. Umann J, Silva RM, Benetti ERR, Guido LA. Stress and coping among nurses of hemato-oncologic units. Rev Rene. 2013; 14(4):783-90.

16. Guido LA, Silva RM, Goulart CT, Kleinübing RE, Umann J. Stress and coping among surgical unit nurses of a teaching hospital. Rev Rene. 2012; 13(2):428-36.

17. Guido LA, Umann J, Stekel LMC, Linch GFC, Silva RM, Lopes LFD. Estresse, Coping e estado de saúde de enfermeiros de clínica médica em um hospital universitário. Ciênc Cuid Saúde. 2009; 8(4):61521.

18. Moreno FN, Gil GP, Haddad MCL, Vannuchi MTO. Estratégias e intervenções no enfrentamento da Síndrome de Burnout. Rev Enferm UERJ. 2011; 19(1):140-5. 